\title{
The Effect of HIV/AIDS on Job Satisfaction amongst the Nurses in the Public Health Sector of Botswana
}

\author{
Keratilwe Bodilenyane \\ Department of Animal Production \\ Ministry of Agriculture \\ P. O. Box 342, Mochudi, Botswana
}

Tel: 267-577-7075 E-mail: kbodilenyane@gov.bw

Baakile Motshegwa (Corresponding author)

Department of Political and Administrative Studies

University of Botswana

Private Bag UB00705, Gaborone, Botswana

Tel: 267-355-2742Ｅ-mail: Motshegwa@mopipi.ub.bw

Received: January 5, 2012

Accepted: February 7, 2012

Published: April 1, 2012

doi:10.5539/ijbm.v7n7p61

URL: http://dx.doi.org/10.5539/ijbm.v7n7p61

\begin{abstract}
The purpose of this paper was to explore the effect of HIV/AIDS on job satisfaction amongstthenurses in the public health sector of Botswana. Despite the intensive research on job satisfaction, it would seem dissatisfaction with work has reached critical levels throughout the society and that the nursing profession is no exception to this growing trend. The current study demonstrates that HIV/AIDS has a negative effect on the satisfaction of the nurses and this supports some of the earlier studies on job satisfaction. Therefore the exploration of the effect of HIV/AIDS on job satisfaction has the potential to aid development of strategies to improve the declining level of job satisfaction among nurses in Botswana.
\end{abstract}

Keywords: Job satisfaction, HIV/AIDS, Nursing, Pay, Botswana

\section{Introduction}

HIV/AIDS has been a pandemic that hit the country of Botswana severely in the early 1990s with Botswana'sprevalence at $35.8 \%$, leading all the countires of Southern Africa (Motshegwa, 2003). Government intensified its effort to curb the scurge but according to The Henry J. Kaiser Foundation report of 2005, the country had not improved its prevalence in that in 2003 the prevalence was still high at $37.3 \%$ while Swaziland leadthe Sub Sahara region with $38.38 \%$. The purpose of the study was to explore the effect of HIV/AIDS on job satisfaction amongst the nurses in the public health sector of Botswana. This is important because the twenty-first century demands that workers take up new roles in the organizations (Nel et al., 2004). Therefore failure to investigate job satisfaction among the nurses in the advent of HIV/AIDS may have dire consequences on the nurses as well as the society at large. There is sufficient empirical evidence that work satisfaction of nurses is important because it tends to affect individuals, organizations, and greater health and social outcomes (Pillay, 2009). This study is important as it interrogates job satisfaction in the context of the Botswana public service and as such contributes to the wider management body of knowledge. As a third world country, Botswana is one of the countries where these kinds of studies are not readily available.

According to the estimates from 2004, about $17.1 \%$ of Botswana's population is HIV-positive (USAID Botswana, 2010). Hence hospitals in Botswana, especially Princess Marina which is a major hospital is struggling to cope with the mounting pressure on staff and resource shortage and the HIV/AIDS crisis (IRIN, 2011). This can put the nurses in an undesirable position to handle their work hence can reduce the level of job satisfaction. Therefore this paper will help elicit information on the feelings that nurses have of their HIV/AIDS job to inform policy. This is important because it takes a brave nurse to make adverse comments about any 
aspect of the job to the employer right in their face, because the odd nurse who does speak his or her mind often lives to regret it (Walters, 1996). Also the hazards associated with HIV/AIDS can make managers reluctant to seek employee's views because it can only stir up trouble.

The health care system in Botswana has Referral hospitals, the District Hospitals, the Primary hospitals and the Clinics. In all this stages the first contact person who even takes the decision to refer the patient to a higher health-care facility is the nurse (Fako, 2000). This is supported by Boonstra et al. (2002), who maintain that nurses have acted as the first contact within the health care system at primary care facilities since the mid-1960s. Hence the nurses form the largest and the heart of health care providers in Botswana. Nurses develop and implement a plan of care and work collaboratively with the patient, the patient's family and other members of a health care team such as physical therapists, medical practitioners, social workers and dieticians. They act as patient's advocates.

The shortage of well-trained health workers is a global problem but low-and middle-income countries, where HIV/AIDS is more prevalent, feel the crisis most acutely. The literature indicates that despite the high prevalence of HIV/AIDS in Botswana, the shortage of nurses has been a problem and it is nowhere near sorted. Nurses are leaving the government institution. Attesting to this is that the recently opened Bokamoso Private Hospital has dealt the public sector service crippling blow (Ganetsang, 2010). According to Tshweneyagae (2007) between 1999 and 2005 about 232 nurses resigned from the public service and about 18 deserted. Even recently, that is in 2006 about 146 nurses resigned while 24 nurses retired (Tshweneyagae, 2007). In addition many Botswana nurses trained under the British system are quickly recruited by employers in Australia, the United Kingdom and the United States and some nurses leave Botswana for the United Kingdom for greener pastures despite the fact that working in one's home country is the norm and most people do not wish to leave their home country. The migration is likely to increase given the work demands brought by HIV/AIDS pandemic in Botswana.

\section{Aims of the Study}

The objective of this study was to explore the effect of HIV/AIDS on job satisfaction amongst nurses in public health sector of Botswana. The following were specific objectives of the study:

- To explore the effect of HIV/AIDS on nurses perception of the nature of their job.

- To explore the effect of HIV/AIDS on nurses perception of their workload

- To explore the effect of HIV/AIDS on nurses perception of their pay

- To explore the effect of HIV/AIDS on nurses perception of their physical working conditions

Job satisfaction is a multifaceted (Lunderen et al., 2005), a multi-dimensional (Weaver et al., 1998) construct with a variety of definitions. The study will adopt the definition by Spector (1996) that summarize most of the definitions and state that what makes a job satisfying or unsatisfying does not depend only on the nature of the job, but also on the expectations that individuals have of what their job should provide. That is, job satisfaction is determined by characteristics both of the individual and the job.

HIV/AIDS is a virus transmitted from one person to another through exchange of body fluids such as blood, semen, breast milk and vaginal secretions (Eugene, 2003). This virus is deadly in that it damages the body's immune system cells and the body becomes vulnerable to illness and infection. Unlike other illnesses there is no cure for HIV/AIDS.

Another equally important term is nursing, which is a healthcare profession for care of the whole society to maintain optimal health and quality of life from birth to death (WHO, 2006).

\section{Literature Review}

\subsection{Maslow's Hierarchy of Needs}

Maslow (1954) developed a five level hierarchy of needs ranging from psychological, safety, social, ego and self-actualization needs.The theory has twofold basis: People continuously want things. People always want more, and what they want depends on what they already have (Nel et al., 2004). Therefore people are never satisfied because as one need is satisfied the other takes its place. Self-esteem and self-respect (as well as the esteem and respect of others) are functions of the type of work people do, rather than of working conditions such as free interaction and good remuneration (Nel et al., 2004). As such self-esteem and self-actualization needs, "associations with others, self-respect gained through the work, and high interest value of the work can serve effectively to induce people" (Pugh, 1970:21). This theory is important because it postulate that for one to be satisfied, the lower needs going up the hierarchy should be fulfilled. 
Despite Maslow's theory being widely used some of his critics pointed out that needs are not arranged in such a rigid hierarchy. This is because different employees may have different values and preferences. For example, some, whose safety needs are not well met, put a lot of energy into relationships and search for love (Edwards, 1997). Hence employees place value in different facets of the job, as opposed to applying their preferences in a rigid manner as provided by Maslow. However, something to be appreciated from this theory is that Maslow himself expressed doubts about validity of a strict ordered hierarchy (Armstrong, 2009). To some extent it can be argued that Maslow acknowledges that the theory can be applied in a more flexible manner.

\subsection{Vroom's Expectancy Theory}

The expectancy theory by Vroom (1954) focuses on outcomes. It says that individuals have different sets of goals and can be motivated if they have certain expectations. The expectancy theory explains how individuals make decisions to arrive at something worthwhile to them. According to this theory there are three elements for arriving at a desired outcome, which are

- Instrumentality

- The valence of an outcome for the individual, and

- The expectancy that a particular act will be followed by a predictable outcome

However in extending on Vroom's idea to make it richer and relevant to motivation, Lawler (1967) notes that in considering rewards, the satisfaction gained by an individual is governed by the difference between the amount of some valued outcome that a person receives and the amount of that outcome he feels he should receive. Lawler (1967) argued that employees are satisfied with a particular facet of their jobs, for example, co-workers and pay, especially when the amount of the facet they perceive that they should receive for performing their work atleast equals the amount they actually receive (Pietersen, 2005). This is quite relevant more especially in this dynamic world because it postulates that employees are satisfied with a particular facet of their job which they place value into it. For example if the nurses feel that the nature of the work is the most important, then they will be satisfied despite the absence of other factors. This theory concurs with Locke's contention that individuals performing the same job may have different levels of satisfaction. This is because each one of them has different level of expectancy on each and every particular facet of their job. In concurrence Nel et al. (2001) assert that each employee has a unique personality and employee's personality differs from one another.

\section{Literature on Dimensions of Job Satisfaction}

The dimensions of job satisfaction are quite many and vary from study to study, hence multidimensional nature of job satisfaction. Inter alia are; interaction (Adamson et al., 1995, Tovey\& Adams, 1999, Adams \& Bond, 2000); self growth and promotion (Tzeng, 2002); praise and recognition (Nolan et al., 1998, Wang, 2002); job security (Nolan et al., 1995); leadership styles (Lee, 1998); organizational policies (Lee, 1998); working conditions (Adamson et al., 1995, Nolan et al., 1995, Tovey\& Adams, 1999); work itself and workload (Tzeng, 2002, Adams \& Bond, 2000, Tovey\& Adams, 1999), and remuneration (Adamson et al., 1995, Tzeng, 2002, Nolan et al., 1995 and Lee, 1998). However only four factors, that is; nature of the job, workload, pay and physical working conditions will be discussed in this paper.

\subsection{Nature of the Job}

The nature of the job has do with how exciting the job is, looking at the quality of workdone. Katz (1964) argued that the individual may find his work so interesting or so much the type of thing he really wants to do that it would take heavy financial inducement to shift to a job less congenial to his interests (Katz, 1964). Armstrong (2009) also assert that most people work to earn a living, but they also work because of the other satisfaction that work brings, such as doing something worthwhile and interesting. In addition desirable work quality increase work satisfaction. According to Maslow (1954) the job that people do will not necessarily satisfy their needs, especially when they are routine or deskilled. For example a computer technician will have a higher level of satisfaction, looking at the fact that the job requires him/her to use the mental skills. This view emphasize that skill variety has a strong effect on job satisfaction, implying that the greater the variety of skills that employees are able to utilize in their jobs, the higher their level of job satisfaction (Ting, 1997).

Hypothesis 1: Thus, it is hypothesised that HIV/AIDS will negatively affect nurse's opinion on the nature of their job.

\subsection{Workload}

The HIV/AIDS pandemic seems to have increased the workload in the nursing profession due to the reason that HIV/AIDS patients are highly dependent on nurses. Nurses have indicated that the increased workload leads to 
stress and fatigue, having to work longer hours, lowering the quality of service provided and poor performance of duties which ultimately reduces the level of job satisfaction (Mafuya, 2005). Burnard (1999) also argued that very demanding workloads where professional standards are not met reduces the level of job satisfaction. Nel et al. (2001) concurs with Burnard and assert that quantitative overload which involves having too much work to do in the time available, lead to job dissatisfaction. Hence nurses are likely to stay with the organization when they are provided a proportionate amount of job autonomy and equitable workloads (Hussami, 2008).

Hypothesis 2: Hence it is hypothesised that HIV/AIDS will negatively influence nurse's perception of their workload.

4.3 Pay

According to Savery (2007) pay is a satisfier in other areas of business and particularly in areas where there has been an increase in awareness of cost containment, and thus one such area is healthcare. This is because nursing has struggled for more than a century for its recognition and rightful place in the healthcare sector (Tshweneyagae, 2007). According to Robbins et al. (2003) employees seek pay systems that are perceived as just, unambiguous, and in line with their expectations.

In South Africa, "nurses were found to be generally dissatisfied, with remuneration being a key contributor to dissatisfaction" (Pillay, 2009:3). Fako (2000) found that among the nurses who earned relatively low incomes, a high proportion (71.6\%) were dissatisfied with their jobs compared to a lower proportion (63.4\%) of those who earned medium income and even lower proportion of those who earned relatively high income. Therefore the nurses who are satisfied with their salary are satisfied with their job. Bull (2005) also argued that such findings are largely consistent with the idea that most employees are socialized in a society where money and benefits are generally sought after and are often used to gauge the importance or the worth of a person.

In an alternative view, there are some nurses whom nursing profession is somewhat born in them. The study conducted by Ravari et al. (2009) on spiritual job satisfaction in Iranian Nursing content, majority of the participant argued that they felt a sense of contentment even when it meant a lower salary and less financial rewards. They attach in spiritual pleasant feelings to the nursing profession, hence felt satisfied with the job. This can be quite confusing because it implies that job satisfaction of nurses is not something that can be nurtured on an individual through offering incentive, rather one is born with.

Hypothesis 3: Therefore, it is hypothesised that HIV/AIDS will negatively influence nurse's perception of the way they view their pay.

\subsection{Physical Working Conditions}

The aspect of physical working conditions has been taken for granted in the workplace, but literature indicates that the physical working conditions can be more important than the job itself in affecting job satisfaction. Most important to note is that physical working conditions is tightly linked to attractiveness of the work environment, be it the safety of the work environment or in the physical execution of tasks (Tawfik, 2006 \&Nel et al., 2000). According to Tawfik (2006) caring for HIV/AIDS patients is not only demanding but risky due to occupational hazards and perceived risks of HIV/AIDS. Certainly working in an environment where HIV/AIDS pandemic is 'food of the day' may lead to nurses asking themselves questions as to why they joined the nursing profession. In concurrence Pillay (2009:01) maintain that, "improving the work environment so that it provides a context congruent with the aspirations and values systems of nurses is more likely to increase the satisfaction of nurses and consequently have a positive effect on individual, organizational and health outcomes".

Hypothesis 4: Thus, it is hypothesised that HIV/AIDS will negatively influence nurse's opinion of their working conditions.

\section{Methodology}

A survey was conducted in six purposively selected hospitals. It was conducted mainly in Primary, District and Referral hospitals where much of the administration work takes place. The nurses who participated in the study were those in Princess Marina Hospital in Gaborone and the catchment areas which were; Scottish Livingstone in Molepolole, Deborah Retief Memorial in Mochudi, Athlone Hospital in Lobatse and Bamalete Lutheran Hospital in Ramotswa.

\subsection{Selection of a Sample and Procedure}

Considering costs and time constraints the researchers sampled a substantial part of each of the population, in the selected hospitals. Since the Department of Clinical Services under the Ministry of Health does not have the sampling frame for the nurses in each and every hospital, the research therefore decided to have a sample size of 
70 which was just estimation from the entire population.

A carefully worded (short and unambiguous) questionnaire, easy to understand and straightforward was personally distributed to the respondents. A cover letter was written and affixed to the questionnaire to explain the purpose of the study. Respondents were told and assured that participation in the study was strictly voluntary. As such the study data was collected anonymously, and respondents were advised not to write any identifying information on the questionnaire.

Convenience sampling was used hence nurses who reported for duty on two selected days made up the sample of the study. The participants were visited from the wards in which they were based on that particular day after getting permission from Hospital Superintended and the Matron. Therefore nurses who did not report for duty on the two selected days were excluded from the study. Even though the sample size was 70; the researchers distributed 20 questionnaires to each selected hospital to increase the response rate. Upon completing the questionnaire the respondents placed them in the provided envelopes, which was then sealed and dropped at the matron's office, where the researcher collected them. With the help of hospital administrators, of 100 questionnaires that were distributed to the respondents, 90 completed questionnaires were returned.

\subsection{Study Instruments}

The biographical questionnaire wasspecifically developed for this study. It solicited information on participant's age, gender, experience and occupational level. Another measure that was utilised is Index of Organizational Reactions (IOR) developed by Dunham \& Smith in 1979 (Fields, 2002), from which the permission to adapt the index was sought. The study adapted some items from IOR which were; the kind of work (the nature of the job) compensation (pay) working conditions and amount of work done (workload). This Index has been tested and has demonstrated reliability, with coefficient alpha values ranging from .82 to .83 (Fields, 2002). For validity purposes, five nurses from Extension 2 Clinic in Gaborone were used for pre-testing the survey before sending it to the real respondents, and the questionnaire modified thereafter.

\subsection{Methods of Data Analysis}

Statistical Package for Social Science (SPSS) was used for data analysis. The multi logistic regression was used to measure or capture the effect of the explanatory variables on the dependent variable. The most important statistic used for multi logistic regression is exponential (B). The exponential (B) shows the odd or the likelihood of the effect of the independent variables on dependent variables. In the model exponential is divided in two components. The first part explains the model's fitness. The goodness or the fitness of the model is deduced from the p- (probability) value which shows the level of significance of the variables included in the model. The other variable used is the chi-square which explains the difference between the intercept and the final variable. If the intercept is equal to the final, it implies that the chi square is zero. This also means that the independent variable can explain or has an effect on the dependent variable. But if the chi square is greater or less than 0 , it implies that the exponential variable has no effect on the dependent variable.

Bivariate Pearson Correlation ( $r$ ) was used to find the relationship between two or more variables. The correlation (r) shows the direction of the relationship which was evident by the corresponding signs of (r).

\subsection{Data Analysis}

The demographic characteristics of the 70 respondents included $31 \%$ males and $69 \%$ females. The age of the respondents ranged from below 25 to 55 years; most of the respondents $47.1 \%$ were aged between 26 to 35 , $14.3 \%$ were below $25,22.9 \%$ were between 36 to 45 and $15.7 \%$ were between 46 to 55 . According to the occupational level the sample consisted of $2.9 \%$ nurse officer I, $40 \%$ registered nurse, $4.3 \%$ nurse officer II, $5.7 \%$ senior officer II, $20 \%$ senior registered nurse, $10 \%$ principal registered nurse, $12.9 \%$ chief registered nurse and $4.3 \%$ other (which the respondents specified as assistant nursing officer). The length of service ranged from less than 5 years to 35 years; most of the respondents $45.7 \%$ have worked for the hospital for 26 to 35 years and $41.4 \%$ worked for 16 to 25 years, $8.6 \%$ worked for less than 5 years and $4.3 \%$ worked for 6 to 15 years.

\subsection{The effect of HIV/AIDS on Organizational Variables}

In order to find the effect of HIV/AIDS on job satisfaction, the nature of the job was captured as the dependent variable and the workload, pay and physical working conditions were captured as independent variables

\subsubsection{Multi Logistic Model}

The model as shown in Table 1 and 3 uses the exponential beta to measure or capture the effect of the explanatory variables on the dependent. In the model exponential is divided in two components. The first part explains the model's fitness. 
The second part is Table $2 \& 4$ on parameter estimates. The most important statistic used for multi logistic regression is exponential (B). The exponential (B) shows the odd or the likelihood of the effect of the independent variables on dependent variables.

Table 2 shows the estimated results of workload, physical working conditions and pay in the advent of HIV/AIDS's effect on the nature of job (the nature of work involved in dealing with HIV/AIDS). According to the findings, an increase in the nurse's workload in the advent of HIV/AIDS increases the odd of getting dissatisfied with their job by $78.1 \%$ as compared to when their workload is decreased. The results also shows that as the amount of work that nurses are expected to do on HIV/AIDS patients affect the way they do their job increases by lunit, the odd of getting dissatisfied with the nature of the job will decrease by $56 \%$ as opposed to those nurses that HIV/AIDS does not affect the way they do their job.

Furthermore, the results show that the physical working conditions have a negative relationship with the nature of their jobs. As nurse's pride in the appearance of their work place in the advent of HIV/AIDS decreases, the odd of nurses that were dissatisfied by the nature of the job increases by $90.4 \%$ as compared to nurses that were satisfied. In addition as the physical working conditions influence the nurse's attitudes unfavourably, in the advent of HIV/AIDS increases by lunit, the odd of nurses being dissatisfied by the nature of the job increases by more than $200 \%$ as compared to those that the physical working conditions have a favourable influence on the way they do their job.

The result also entails that in the advent of HIV/AIDS as the nurses feel the amount of money they make is poor increases by lunit, the odd of nurse's being dissatisfied by the nature of the job increases by more than $100 \%$ as compared to those nurses that feel the pay is good. In addition as the nurses feel the way pay is handled make them to be dissatisfied increases by 1 unit, the odd of nurses getting dissatisfied with the nature of the job increases by $55 \%$ as compared to those who were satisfied.

Table 4 shows the effect of HIV/AIDS on workload, physical working conditions, and pay in relation to the nature of the job (the way nurses feel about the kind of HIV/AIDS work they do). According to the findings, as the HIV/AIDS related work increases, the odd of nurses getting dissatisfied decreases by $38.9 \%$ as compared to when the workload is decreased. In addition as the amount of work nurses are expected to do increases by 1 unit as a result of HIV/AIDS, the odd of nurses getting dissatisfied with the nature of the job increases by more than $200 \%$ as opposed to those who are satisfied.

As nurse's pride in the appearance of the workplace decreases by 1 unit, the odd of nurses that were dissatisfied with the nature of the job increases by more than $100 \%$ as opposed to those that were satisfied. In addition as the physicalworking conditions influence the nurse's attitudes unfavourably increases by 1 unit, the nurses are more likely to be dissatisfied (more than $800 \%$ ) as opposed to nurses that do not mind about the physical working conditions.

The results also show that in the advent of HIV/AIDS, as the nurses feel the amount of money they make is poor increases by lunit, the odd of nurse's being dissatisfied by the nature of the job increases by $64 \%$ as compared to those nurses that feel the pay is good. In addition as the nurses feel the way pay is handled make them to be dissatisfied increases by 1 unit, the odd of nurses getting dissatisfied with the nature of the job increases by $56 \%$ as compared to those who are satisfied.

\subsubsection{Relationship between the Four Organizational Variables}

The tool that was used for this analysis is Bivariate Pearson Correlation (r) (2-tailed) at various level of significant but mostly accepted at 5\%. It implies that at significant value more than $5 \%$, the current study assumes that the relationship is not significant between the variable in question. The correlation (r) shows the direction of the relationship which was evident by the corresponding signs of (r).

This information is contained in Table 5 which shows the relationship between and among the nature of job, workload, physical working conditions, and the pay. There is a low positive significant relationship between how nurses feel about the kind of HIV/AIDS work they do (0.217) and the nature of the job, which is significant. The nature of the job also has a low positive relationship with the nurses pride in the appearance of the work place, in the advent of HIV/AIDS (0.262) and is also significant, and a low negative insignificant relationship with the way pay is handled to make it worthwhile for a person to work especially hard on HIV/AIDS patients (-0.014).

How nurses feel about the kind of HIV/AIDS work they do has a low positive significant relationship with the amount of work they are expected to do on HIV/AIDS (0.322), low positive significant relationship with the pride they take in the appearance of the work place in the advent of HIV/AIDS (0.289), and a low negative insignificant relationship with the way pay is handled to make it worthwhile for a person to work especially hard 
on HIV/AIDS patients (-0.047).

The amount of work that nurses are expected to do on HIV/AIDS patients has a moderate positive significant relationship with the way nurses feel about workload in the advent of HIV/AIDS (0.540), low significant relationship with the pride nurses take in the appearance of the work place in the advent of HIV/AIDS (0.191), and low positive significant relationship with the pay in the advent of HIV/AIDS's workload (0.250).

The way pay is handled in the advent of HIV/AIDS has a low positive significant relationship with the physical working conditions in the advent of HIV/AIDS (0.262), low negative insignificant relationship with the nature of work involved in dealing with HIV/AIDS (-0.014) and low negative insignificant relationship with the way nurses feel about the workload in the advent of HIV/AIDS (-0.47).

\section{Discussion of Results}

According to Walters (1996:6) "there is no doubt that employee consultation, however conducted, is often the tin-opener to a huge can of worms". This is true for how HIV/AIDS affect job satisfaction among the nurses in the public health sector of Botswana. Even if the nurses keep on working, despite the risks and demands of HIV/AIDS at the workplace, it does not mean they are satisfied, because after all people need 'bread on top of the table'. The findings from the current study demonstrate that when the nature of the job is manipulated by other factors of job satisfaction in the advent of HIV/AIDS, nurses experience a reduced level of satisfaction, as illustrated in Table 2 and 4.

\subsection{Workload}

The results indicate that the increase in workload due to HIV/AIDS has a negative effect on the nurse's attitude towards the nature of the job. An increase in the nurse's workload due to HIV/AIDS increases the odd of getting dissatisfied with their job as compared to when their workload is decreased. Also the way nurses feel about the nature of HIV/AIDS job they do has a low positive significant relationship with the amount of work they are expected to do on HIV/AIDS patients, and this support hypothesis one and two. Theresults of the current study concurs with Tshweneyagae (2007) who argued that the advent of HIV/AIDS has changed the nursing profession and has made services provided by the nurses to be complex. This is because HIV/AIDS patients require more specialized care and longer treatment, which can be a burden to the nurses. George (2009) also argued that the more routinization employees experience in their workload the less satisfied they are with the nature of the job. In addition, increased workload due to HIV/AIDS may end up making the nurses to be bored in the workplace, hence reduced level of job satisfaction.

Tshweneyagae (2007) further argued that HIV/AIDS has resulted in overcrowding, and it interfered with the way nurses have been rendering care to the patients. According to UN (2004) with the advent of HIV/AIDS the life expectancy at birth fell from 65 years in 1990-1995 to less than 40 years in 2000-2005, a figure about 28 years lower than it would have been without HIV/AIDS. Hence the HIV/AIDS pandemic in Botswana has led to the nurses taking on expanded roles. Also the Antiretroviral (ARV) therapy was launched in Botswana in 2002 and upon their introduction it was hoped that they would reduce the admission pressure in hospitals (IRIN, 2011). According to the Superintendent of Princess Marina Hospital Dr Moffat in 2004, this did not work because people who seek treatment do so when they are already in the terminal stage of illness, a situation which forces to re-admit them (IRIN, 2011). Hence the long-term demand for HIV/AIDS treatment in hospitals is slowly and surely exceeding the available medical personnel (Rollnick, 2002). Due to HIV/AIDS pandemic, there is over utilization of nurses in reducing waiting lists for ARV across the country and sustaining the lifetime of monitoring and follow-up care that is required for those on therapy (Tawfik, 2006). The nurses are thus required to cope with the psychosocial stress of offering palliative care to increasing numbers of dying patients (Tawfik, 2006).

Furthermore when the health care sector is overwhelmed with additional responsibilities due to HIV/AIDS some nurses end up quitting the job and seeking employment somewhere else. This is supported by the Assistant Minister of Health Mr Matlhabaphiri, who argued that the workload brought by HIV/AIDS and related opportunistic illness is one push factors (Ganetsang, 2010). When the nurses quit the nursing profession their posts remain vacant for quite some time, hence increased workload to the remaining nurses. Additional responsibilities also imply that they will be high patient-to-nurse ratio. According to WHO (2008) the work of at least 23 health workers (doctors, nurses or midwives) per 10000 population is estimated to be necessary to support the delivery of the basic interventions required to achieve the MDGs for health. Botswana has 9 health workers (as defined above) per 10000 population (IRIN, 2011). Hence the expanded scope of nursing practice due to HIV/AIDS takes toll on the work lives of the nurses. 


\subsection{Pay}

Considering the HIV/AIDS job nurses are not satisfied with their pay. Hence the results of the current study support hypothesis 3, that HIV/AIDS will negatively influence nurses perception of the way they view their pay.The nurses feel the amount of money they make is poor, inadequate and reported that the way pay is handled discourages hard work. The findings are consistent with those of Robbins et al. (2003), Pillay (2009), Fako (2000), and Bull (2005) who found that the nurses who earned relatively low incomes were dissatisfied with their job. Considering the risks and demands of the nursing profession, nurses would expect their pay systems to be sought considering all this, of which failure will lead to a declining level of job satisfaction. This is because individuals get satisfied when they get what they expect from their job; in this case, increased rewards for essential role they play in the health care sector.

In an alternative view, Ravari et al. (2009) had some participants saying that even after 25 years of service; they go to the hospital eagerly and enthusiastically. Participants said they could have had better posts and be in a better position, but what really matters to them is the patients' contentment. The participants described nursing as a divine profession and stated that those who choose this career need to be innately interested in serving and helping humankind (Ravari et al., 2009). Maybe to this breed of nurses' issues such as HIV/AIDS cannot be source of dissatisfaction in their job. This could be another reason why even to date the researchers have not found the best remedy to reduce the declining level of job satisfaction among the nurses. The nursing profession according to Ravariet al. (2009) postulates that only those who have the interest and affection for the nursing profession with all its risks and challenges should take it, it cannot be forced or instilled on people, and one is born with the enthusiasm for it.

\subsection{Physical Working Conditions}

Table 2 and 4 demonstrate that as nurse's pride in the appearance of the workplace decreases, the odd of nurses that were dissatisfied with the nature of the job increased as opposed to those that were satisfied. Furthermore the nature of the job has a positive correlation with the physical working conditions in the advent of HIV/AIDS. Hence the findings of the current study support hypothesis 4 . The findings are consistent with those of Pillay (2009) and Vorster et al. (2005) who argued that nurses are restricted from working to their full potential and providing total commitment as a result of their constrained environment. Pillay (2009) further asserted that they should be availability of protective materials and functional equipment to safeguard nurses from unnecessary accidents, as well the implementation of structures and processes to help nurses improve their personal safety skills.

The reduced level of job satisfaction in the advent of HIV/AIDS could be attributed to the risk of infection, risk of injury due to this deadly disease. The study by Tawfik (2006) has shown that nurses are a group that is at highest risk of infection in the workplace. This may lead to high turnover in the nursing profession with fear of getting infected in the workplace (Al-Hussami et al., 2008 and Berger \& Lambert, 1968). Berger and Lambert (1968) asserted that an employee quitting a job is based on their experience with an organization, which results from attitudes and values developed during their stay with the organization. This is further supported by Vroom (1964) that the common ingredient is the notion that the attractiveness of a social system to a person and the probability that he will voluntarily withdraw from the organization is related to satisfaction and deprivations incurred as a result of organizational membership. Based on their experience with the organization nurses may intend to leave their job due to bad physical working conditions.

Furthermore the results in Table 5 reveal that the amount of work that nurses are expected to do on HIV/AIDS patients have a low insignificant relationship with the nurse's pride in the appearance of the work place in the advent of HIV/AIDS, and low positive significant relationship with the pay in the advent of HIV/AIDS. The positive relationship between pay and the workload could be attributed to the expectation of having their pay increased as the workload increases due to HIV/AIDS.

Furthermore Table 5 demonstrates that the way pay is handled in the advent of HIV/AIDS has a low positive significant relationship with the physical working conditions in the advent of HIV/AIDS. This could be attributed to the reason that nurses would expect their pay to be sought considering the risks of the environment they work in. The HIV/AIDS pandemic has made the nursing profession to be a highly risk job. Therefore nurses might expect high wages to compensate them for the risks they may incur at the workplace. Hence the government should pay attention to the nurses' expectations on pay.

\section{Limitations of the Study}

One big limitation of the study was in terms of method of data collection. The sample was taken from Gaborone 
and the catchment areas, which may not be representative of the nurses in the public health sector of Botswana. In addition the paper adapted Index of Organizational Reactions (IOR) and it may be difficult for other researchers to compare their results with the results of the current study.

\section{Conclusion of Findings}

The findings of the current study have revealed that factors of job satisfaction are related or interdependent given the advent of HIV/AIDS. For example nurses may be satisfied with the nature of HIV/AIDS job, but if HIV/AIDS makes the physical working conditions obnoxious, the workload to be high and with low pay after the hard work, the nurses will experience reduced level of job satisfaction. This is because nurses or everyone else would aspire to work in an environment where they are protected from physical and emotional harm. For this reason, working in a highly risky environment where there are high workloads due to dreadful diseases such as HIV/AIDS reduces the level of job satisfaction among the nurses. In a nutshell nurses have demonstrated that their job is not pleasurable due to HIV/AIDS which makes it thorny to attain social, ego and self-actualization needs, hence a reduced level of satisfaction.

\section{Recommendations}

The government should aim at sensitizing the nurses about the nature of the nursing profession at an earlier stage. There is need to adequately emphasize the risks and demands in the nursing profession during the nurses training process. This is important because it is evident that nurses fear the risks inherent in their profession. Therefore nurses should live by a motto. Every day they walk in the workplace, the motto should be $100 \%$ elimination of accidental exposure to the virus in the workplace. To be more successful, efforts should be designed to make the hospitals a safe place to work at, that is, they should be programs aimed at enhancing occupational safety. In addition the health care managers should come up with coping strategies such as counselling and psychosocial support for nurses to deal with the trauma they face in the workplace.There is a need to increase the level of knowledge or and expertise among lay counsellors to ensure coordinated effort, so that their hand can be felt more in reducing the HIV/AIDS workloads.

In addition nurses have shown high dissatisfaction with their pay, looking at the nature of the job they do. Nursing is a hazardous and demanding profession; hence need to come up with pay systems that will provide for incentives such as risk allowances. This will also show the recognition and appreciation of the essential role played by the nurses in the society.

Nurses have shown high dissatisfaction with their physical working conditions hence need for health care managers to provide nurses with all necessary equipment that will increase the safety in their work environments and even improve the quality of service they provide to the patients. According to Nel et al. (2001) the most effective barriers are made of treated fabrics or synthetic materials that do not allow water or other liquids (blood or body fluids) to penetrate them. Even though theseequipment can be expensive it is important to put the safety of nurses before the price.

However, in order for the results of addressing HIV/AIDS to come to fruition nurses should collaborate with the government amicably. Nurses should understand that one essential component of work is that, "work involves effort and persistence (it is not wholly pleasurable although there may be pleasurable elements in it)", (Armstrong 2008:208). Hence in some cases they should reduce themselves down to public servants. They should find their organizational behaviour rewarding in itself, not so much because their job is interesting, rewarding or gives them a chance to express their skill, but because they have taken over the goals of the organization as their own. This is because literature has indicated that a person who has identified himself with the goals of his own particular organization and its specific problems, potentialities and progress will stay with it, moreover, is willing to accept other assignments not specified on the job description (Katz, 1964). In addition, Katz (1964) accentuated that for effective organizational functioning many members must be willing on occasion to do more than their job descriptions specify. The government of Botswana insists on separation of jobs in the health care sector which has led to chaos. Therefore the government should realize that if the hospitals are to follow the letter of the law according to job descriptions and protocol, it would soon grind to a halt. There have to be many actions of mutual cooperation in addressing HIV/AIDS so as to make the nursing profession a decent job to be aspired by all.

\section{Suggestions for Future Research}

It is suggested that future research be conducted on job satisfaction among nurses because there is an information vacuum in this subject area. Research should focus on exploring quite a number of factors on job satisfaction so as to provide insight on what is really causing the decline in the level of job satisfaction among the nurses. This 
will elicit information to help government have a better understanding of which job facets are of substance to the nurses.

\section{References}

Armstrong, M. (2006). Human Resource Management Practice. United Kingdom: Kogan Page Limited.

Armstrong, M. (2009). Human Resource Management Practice. United Kingdom: Kogan Page Limited.

Al-Hussami, M. (2008). A study on nurse's job satisfaction: The relationship to organizational commitment, perceived organizational support, transactional leadership, transformational leadership and level of education. European Journal of Scientific Research, 22 (2), 286-295.

Barriball, L., \& Billie, C. K. (2007). Impact of job satisfaction components on intent to leave and turnover for hospital-based nurses; a review of the research literature. International Journal of Nursing Studies, 44(2), 297-314.

Berger, S. M., \& Lambert, W. (2000). Stimulus-response theory in contemporary social psychology. In Lindzey G. \& Aronso, E. (eds.), The Handbook of social psychology. Mass: Addison-Wesley.

Boonstra, E., Lindbaek, M., Khulami, P., Ngome, E., \& Fugeli, P. (2002). Adherence to treatment guidelines in primary health care facilities in Botswana. Tropical Medicine and International Health, 7, 178-86. http://dx.doi.org/10.1046/j.1365-3156.2002.00842.x

Bull, I. H. F. (2005). The relationship between job satisfaction and organizational commitment amongst high school teachers in disadvantaged areas in the Western Cape. Unpublished.

Burnard, P., Morrison, P., \& Phillips, C. (1999). Job satisfaction amongst nurses in an interim secure forensic unit in Wales. Australian and New Zealand Journal of Mental Health Nursing, 8, 9-18. http://dx.doi.org/10.1046/j.1440-0979.1999.00125.x

Cole, G. A. (2002). Personnel and Human Resource Management. London: BookPower.

Edwards, D. (1997). Motivation and Emotion. In Louw D. A. \& Edwards D.J.A. (eds.), Psychology: An introduction for students in Southern Africa (pp. 424-473). Heinemann Higher \& Further Education (Pty) Ltd: Sandton.

Fako, T. T. (2000). Job satisfaction among the nurses in Botswana. Society in Transition, 31(1), 10-12.

Fields, D. L. (2002). Taking the measure of work: A guide to validate scales for organizational research and diagnosis. Thousand Oaks: Sage.

Ganetsang, G. (2010). Sick and tired- Botswana Public Health Sector. Sunday Standard, 19 July.

George, A. (2009). Registered nurses job satisfaction in Navy Hospitals. Military Medicine, 174, 1-76.

Hussami, M. A. (2008). A study of nurses' job satisfaction: The relationship to organizational commitment, perceived organizational support, transactional leadership, transformational leadership and level of education. European Journal of Scientific Research, 2, 286-295.

IRIN. (2011). Humanitarian news \& analysis, 'Botswana main referral hospital facing crisis'. [Online] Available: http://www.irinnews.org/report.aspx?report=51452 (08 February 2011)

Katz, D. (1964). The motivational basis of organizational behaviour. Behavioural Science, 9, 131-46. http://dx.doi.org/10.1002/bs.3830090206

Lawler, E. E. (1967). Job Design and Employee Motivation. In Gruneberg, M. (ed.). Job satisfaction. Gower Press.

Lawler, E. E., \& Porter, L.W. (1967). Antecedent Attitudes of Effective Managerial Performance. Organizational Behaviour \& Human Performance, 2, 122-42. http://dx.doi.org/10.1016/0030-5073(67)90026-8

Li, G., Barriball, K. L., \& While, A. E. (2009). Job satisfaction of nurse teachers: A literature review. Part II: Effects and related factors. Nurse Education Today, 29, 477-487.

Lunderen, S., Nordholm, L., \& Segesten, K. M. (2005). Job satisfaction in relation to change to all-RN staffing. Journal of Nursing Management, 13, 322-28.

Mafuya, N. P., \& Peltzer, L K. (2005). Perceived HIV/AIDS impacts among staff in tertiary institutions in the Eastern Cape, South Africa. Journal of Social Aspects of HIV/AIDS, 2, 277-285.

Maslow, A. (1954). Motivation and personality. New York: Harper and Row. 
More, H.W., \& Wegner, W.F. (1992). Behavioural Police Management. New York: Macmillan Publishing Company.

Motshegwa, B. (2003). Impact of HIV/AIDS in Botswana and on the Education Workforce. A paper presented at the conference on Crafting Strategies for responding to the Impact of AIDS on the Sub-Saharan Africa Education Workforce, Washington DC. 17-18 November 2003 and at National Academy of Public Administration Fall meeting, Washington DC November 20 -22, 2003. [Online] Available: $\mathrm{http}: / /$ www.napawash.org/pc_international_affairs/A3_B1.pdf

Motshegwa, B. (2008). The relationship between equity, pay satisfaction, affective commitment and intention to turnover: an empirical test in Botswana. The University of Newcastle, Australia. Unpublished PhD thesis.

Nel, P. S., Dyk Van, P. S., Haasbroek, G. D., Schultz, H. B., Sono,T., \& Werner, A. (2001). Human Resource management. (6th ed.). South Africa: Oxford University, Press.

Norton, G. (1997). Industrial and Organizational Psychology. In Louw D. A. \& Edwards D.J.A. (eds.), Psychology: An introduction for students in Southern Africa (pp. 323-780). Heinemann Higher \& Further Education (Pty) Ltd: Sandton.

Parson, S. K., Simmons, W. P., Penn, K., \& Furlough, M. (2003). Satisfaction and turnover among nursing assistants: The results of a state-widesurvey. Journal of Gerontological Nursing, 29, 51-58.

Pietersen, C. (2005). Job satisfaction of hospital nursing staff. SA Journal of Human Resource Management, 3 (2), 19-25.

Pillay, R. (2009). Work satisfaction of professional nurses in South Africa: a comparative analysis of the public and private sectors. Human Resource for Health, 7, 1-15. http://dx.doi.org/10.1186/1478-4491-7-15

Pugh, D. S. (ed). (1970). Management and Motivation. Great Britain: Richard Clay.

Ravari, A., Vanaki, Z., Houmann, H., \& Anooshirvan, K. (2009). Spiritual job satisfaction in an Iranian nursing context. Nursing Ethics, 16 (1), 19-30. http://dx.doi.org/10.1177/0969733008097987

Robbins, S. P., Odendaal, A., \& Roodt, G. (1998). Organizational behaviour and Southern African perspectives. Cape Town: Pearson Education.

Rollnick, R. (2002). Botswana's high-stake assault on AIDS: An African test case for wide distribution of life long-prolonging medicines. Africa recovery, 16, (2), 4.

Savery, L. K. (2007). The perceived influence of different items on the job satisfaction of nurses in an Australian hospital is examined. The Journal of Job Satisfaction and Nurses. EmeraldBackfiles.

Selebi C., \& Minnaar A. (2007). Job satisfaction among nurses in a public hospital in Gauteng. Research Article.

Spector, P. (1996). Job Satisfaction. Thousand Oaks, CA: Sage.

Tawfik, L. (2006). The impact of HIV/AIDS on the health workforce in developing countries. The World Health Report.

The Henry J Kaiser Foundation. (2005). The HIV/AIDS Epidemic in Botswana. [Online] Available: http://www.kff.org/hivaids/upload/7353.pdf ( ${ }^{\text {th }}$ Febraury 2012).

Ting, Y. (1997). Determinants of job satisfaction of federal employees. Public Personnel Management, 26, 313-334.

Tovey, E. J., \& Adams, A. E. (1999). The changing nature of nurses' job satisfaction: an exploration of sources of satisfaction in the 1990s. Journal of Advanced Nursing, 30(1), 150-158. http://dx.doi.org/10.1046/j.1365-2648.1999.01059.x

Tshweneyagae, G.T. (2007). Migration of nurses: is there any other option? [Online] Available: http://www.mmegi.bw/index.php?sid=18aid=298\&dr=2008/June/Fridayb (10 October 2011).

United Nations. (2004).

USAID. (2010). Botswana HIV/AIDS Health Profile. [Online] Available: http://www.usaid.gov (10 October 2010)

Vorster, M., Olckers, C., Buys, M. A., \& Schaap, P. (2005). The construct equivalence of the job diagnostic survey for diverse South African cultural groups. Journal of Industrial Psychology, 31, 31-37.

Vroom, V. H. (1964). Some personality determinants of the effects of participation. Englewood Cliffs: Prentice 
Hall.

Walters, M. (1996). Employee Attitude and Opinion Survey. Britain: Short Run Press.

Weaver, J., Soutar, G. N., \& Savery, L. K. (1998). Western Australian Police Union Study. Western Australian Police Union. Perth.

World Health Organization. (2006). Taking stock: Health Worker shortages and responses to AIDS. [Online] Available: http://www.who.int/hiv/pub/advocacy/ttr/en/index.html (14 September 2010)

Table 1. Model Fitting Information 1

\begin{tabular}{|c|c|c|c|c|}
\hline \multirow{2}{*}{ Model 1 } & Model Fitting Criteria & \multicolumn{3}{|c|}{ Likelihood Ratio Tests } \\
\cline { 2 - 5 } & $\mathbf{- 2 ~ L o g ~ L i k e l i h o o d ~}$ & Chi-Square & Df & Sig. \\
\hline Intercept Only & 75.397 & & & .044 \\
\hline Final & 59.501 & 15.896 & 8 &. \\
\hline
\end{tabular}

Table 1 shows the model is significant at critical value of $5 \%$. It also shows that there is a significant difference between the intercept and the factors influencing the nature of the job. This can be deduced with the chi-square value.

Table 2. Parameter Estimates

\begin{tabular}{|c|c|c|c|c|c|c|}
\hline \multicolumn{2}{|c|}{} & & & & & \\
\hline Nature of the job & Dissatisfied & -1.071 & 1.150 & .868 & 1 & \\
\hline $\mathrm{X}_{1}$ & increased workload & 0.577 & 0.721 & 0.640 & 1 & 1.781 \\
\cline { 2 - 7 } & decreased workload & 0 &. &. & 0 &. \\
\hline \multirow{2}{*}{$\mathrm{X}_{2}$} & affect my job & -0.828 & 0.746 & 1.234 & 1 & 0.437 \\
\cline { 2 - 7 } & does not affect job & 0 &. &. & 0 &. \\
\hline \multirow{2}{*}{$\mathrm{X}_{3}$} & Little & .644 & 0.645 & 0.998 & 1 & 1.904 \\
\cline { 2 - 7 } & great deal & 0 &. &. & 0 &. \\
\hline \multirow{2}{*}{$\mathrm{X}_{4}$} & Unfavourable & 1.173 & 0.813 & 2.082 & 1 & 3.232 \\
\cline { 2 - 7 } & Favourable & 0 &. &. & 0 &. \\
\hline $\mathrm{X}_{5}$ & Poor & 0.823 & 0.775 & 1.128 & 1 & 2.277 \\
\cline { 2 - 7 } & Good & 0 &. &. & 0 &. \\
\hline $\mathrm{X}_{6}$ & Dissatisfaction & -.596 & 0.823 & 0.525 & 1 & 1.551 \\
\cline { 2 - 7 } & Satisfaction & 0 &. &. & 0 &. \\
\hline $\mathrm{X}_{7}$ & $36-55$ & -1.286 & 0.644 & 3.991 & 1 & 0.276 \\
\hline & $0-35$ & 0 &. &. & 0 &. \\
\hline $\mathrm{X}_{8}$ & $16-35$ & -0.127 & 0.882 & 0.021 & 1 & .881 \\
\cline { 2 - 7 } & $0-15$ & 0 &. &. & 0 &. \\
\hline
\end{tabular}

Table 3. Model Fitting Information 2

\begin{tabular}{|l|l|l|l|l|}
\hline \multirow{4}{*}{ Model 2 } & Model Fitting Criteria & \multicolumn{3}{|l|}{ Likelihood Ratio Tests } \\
\cline { 2 - 5 } & $\mathbf{- 2}$ Log Likelihood & Chi-Square & Df & Sig. \\
\hline Intercept Only & 78.723 & & & \\
\hline Final & 55.797 & 22.925 & 8 & .003 \\
\hline
\end{tabular}

Table 3 shows the model is significant at critical value of $1 \%$. It also shows that there is a significant difference between the intercept and the factors influencing the way the nurses feel about the kind of HIV/AIDS work they do (nature of the job). This can be deduced from the chi-square value. 
Table 4. Parameter Estimates

\begin{tabular}{|c|c|c|c|c|c|c|}
\hline & & $\mathrm{B}$ & Std. Error & Wald & df & $\operatorname{Exp}(B)$ \\
\hline \multirow[t]{2}{*}{$\mathrm{X}_{1}$} & increased workload & -0.492 & 0.782 & 0.396 & 1 & 0.611 \\
\hline & decreased workload & 0 & & & 0 & . \\
\hline \multirow[t]{2}{*}{$\mathrm{X}_{2}$} & affect my job & 1.371 & 0.772 & 3.156 & 1 & 3.941 \\
\hline & does not affect my job & 0 & . & - & 0 & . \\
\hline \multirow[t]{2}{*}{$\mathrm{X}_{3}$} & Little & 0.847 & 0.722 & 1.377 & 1 & 2.332 \\
\hline & great deal & 0 & & & 0 & . \\
\hline \multirow[t]{2}{*}{$\mathrm{X}_{4}$} & Unfavourable & 2.264 & 0.994 & 5.188 & 1 & 9.623 \\
\hline & Favourable & 0 & & & 0 & . \\
\hline \multirow[t]{2}{*}{$\mathrm{X}_{5}$} & Poor & 0.496 & 0.827 & 0.359 & 1 & 1.642 \\
\hline & Good & 0 & . & 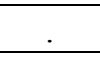 & 0 & . \\
\hline \multirow[t]{2}{*}{$\mathrm{X}_{6}$} & Dissatisfaction & -1.633 & 0.921 & 3.144 & 1 & 1.56 \\
\hline & Satisfaction & 0 & & & 0 & . \\
\hline \multirow[t]{2}{*}{$\mathrm{X}_{7}$} & $36-55$ & 0.007 & 0.677 & 0.000 & 1 & 1.007 \\
\hline & $0-35$ & 0 & & & 0 & 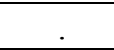 \\
\hline \multirow[t]{2}{*}{$\mathrm{X}_{8}$} & $16-35$ & 1.910 & 1.066 & 3.213 & 1 & 6.754 \\
\hline & $0-15$ & 0 & 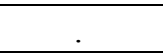 & & 0 &. \\
\hline
\end{tabular}

Table 5. Relationship between the Organizational Variables

\begin{tabular}{|c|c|c|c|c|c|c|c|c|c|}
\hline & & $\begin{array}{c}\text { The } \\
\text { nature } \\
\text { of } \\
\text { work } \\
\text { in } \\
\text { dealing } \\
\text { with } \\
\text { HIV/ } \\
\text { AIDS }\end{array}$ & $\begin{array}{c}\text { how do } \\
\text { you feel } \\
\text { about the } \\
\text { kind of } \\
\text { HIV/ } \\
\text { AIDS } \\
\text { work you } \\
\text { do }\end{array}$ & $\begin{array}{l}\text { I feel the } \\
\text { advent of } \\
\text { HIV/ } \\
\text { AIDS has } \\
\text { made my } \\
\text { workload }\end{array}$ & $\begin{array}{c}\text { how } \\
\text { work on } \\
\text { HIV/ } \\
\text { AIDS } \\
\text { influence } \\
\text { your } \\
\text { attitude }\end{array}$ & $\begin{array}{l}\text { how much } \\
\text { pride can } \\
\text { you take in } \\
\text { the } \\
\text { appearance } \\
\text { of your } \\
\text { workplace }\end{array}$ & $\begin{array}{c}\text { how } \\
\text { physical } \\
\text { working } \\
\text { conditions } \\
\text { influence } \\
\text { your } \\
\text { attitude }\end{array}$ & $\begin{array}{l}\text { I feel the } \\
\text { amount } \\
\text { of money } \\
\text { I make is }\end{array}$ & $\begin{array}{l}\text { does the } \\
\text { way pay is } \\
\text { handled } \\
\text { encourage } \\
\text { hard work }\end{array}$ \\
\hline \multirow{2}{*}{$\begin{array}{c}\text { The nature of } \\
\text { work involved } \\
\text { in dealing with } \\
\text { HIV/AIDS }\end{array}$} & $\begin{array}{c}\text { Pearson } \\
\text { Correlation }\end{array}$ & 1 & .217 & .082 & .003 & .262 & .302 & .153 & -.014 \\
\hline & $\begin{array}{l}\text { Sig. (2- } \\
\text { tailed) }\end{array}$ & & .071 & .501 & .983 & .029 & .011 & .207 & .911 \\
\hline \multirow{2}{*}{$\begin{array}{l}\text { how do you } \\
\text { feel about the } \\
\text { kind of } \\
\text { HIV/AIDS } \\
\text { work you do }\end{array}$} & $\begin{array}{c}\text { Pearson } \\
\text { Correlation }\end{array}$ & .217 & 1 & .259 & .322 & .289 & .393 & .052 & -.047 \\
\hline & $\begin{array}{l}\text { Sig. (2- } \\
\text { tailed) }\end{array}$ & .071 & & .031 & .007 & .016 & .001 & .671 & .698 \\
\hline \multirow{2}{*}{$\begin{array}{l}\text { I feel the } \\
\text { advent of } \\
\text { HIV/AIDS has } \\
\text { made my } \\
\text { workload }\end{array}$} & $\begin{array}{c}\text { Pearson } \\
\text { Correlation }\end{array}$ & .082 & .259 & 1 & .540 & .127 & .227 & .012 & -.183 \\
\hline & $\begin{array}{l}\text { Sig. (2- } \\
\text { tailed) }\end{array}$ & .501 & .031 & & .000 & .299 & .059 & .918 & .130 \\
\hline \multirow{2}{*}{$\begin{array}{c}\text { how work on } \\
\text { HIV/AIDS } \\
\text { influence your } \\
\text { attitude }\end{array}$} & $\begin{array}{c}\text { Pearson } \\
\text { Correlation }\end{array}$ & .003 & .322 & .540 & 1 & .191 & .230 & .250 & .114 \\
\hline & $\begin{array}{l}\text { Sig. (2- } \\
\text { tailed) }\end{array}$ & .983 & .007 & .000 & & .118 & .057 & .038 & .352 \\
\hline \multirow{2}{*}{$\begin{array}{l}\text { how much } \\
\text { pride can you } \\
\text { take in the } \\
\text { appearance of } \\
\text { your } \\
\text { workplace }\end{array}$} & $\begin{array}{c}\text { Pearson } \\
\text { Correlation }\end{array}$ & .262 & .289 & .127 & .191 & 1 & .555 & .154 & .178 \\
\hline & $\begin{array}{l}\text { Sig. (2- } \\
\text { tailed) }\end{array}$ & .029 & .016 & .299 & .118 & & .000 & .206 & .143 \\
\hline \multirow{2}{*}{$\begin{array}{l}\text { How physical } \\
\text { working } \\
\text { conditions } \\
\text { influence your } \\
\text { attitude }\end{array}$} & $\begin{array}{c}\text { Pearson } \\
\text { Correlation }\end{array}$ & .302 & .393 & .227 & .230 & .555 & 1 & .228 & .262 \\
\hline & $\begin{array}{l}\text { Sig. (2- } \\
\text { tailed) }\end{array}$ & .011 & .001 & .059 & .057 & .000 & & .057 & .028 \\
\hline \multirow{2}{*}{$\begin{array}{c}\text { I feel the } \\
\text { amount of } \\
\text { money I make } \\
\text { is }\end{array}$} & $\begin{array}{c}\text { Pearson } \\
\text { Correlation }\end{array}$ & .153 & .052 & .012 & .250 & .154 & .228 & 1 & .502 \\
\hline & $\begin{array}{l}\text { Sig. (2- } \\
\text { tailed) }\end{array}$ & .207 & .671 & .918 & .038 & .206 & .057 & & .000 \\
\hline \multirow{2}{*}{$\begin{array}{l}\text { does the way } \\
\text { pay is handled } \\
\text { encourage } \\
\text { hard work }\end{array}$} & $\begin{array}{c}\text { Pearson } \\
\text { Correlation } \\
\end{array}$ & -.014 & -.047 & -.183 & .114 & .178 & .262 & .502 & 1 \\
\hline & $\begin{array}{l}\text { Sig. (2- } \\
\text { tailed) }\end{array}$ & .911 & .698 & .130 & .352 & .143 & .028 & .000 & \\
\hline
\end{tabular}




\section{Appendixes}

The interpretation of the exponential (B) of various variables are explained

\section{Model Specification}

$$
\log \left[\frac{p}{1-p}\right]=\mathbf{Y}=\quad \boldsymbol{\beta}_{0}+\boldsymbol{\beta}_{1} \mathbf{X}_{1}+\boldsymbol{\beta}_{2} \mathbf{X}_{2}+\boldsymbol{\beta}_{3} \mathbf{X}_{3}+\boldsymbol{\beta}_{4} \mathbf{X}_{4}+\boldsymbol{\beta}_{5} \mathbf{X}_{5}+\boldsymbol{\beta}_{6} \mathbf{X}_{6}+\boldsymbol{\beta}_{7} \mathbf{X}_{7}+\boldsymbol{\beta}_{8} \mathbf{X}_{8}+\varepsilon
$$

\section{Definition/description of variables}

\section{Dependent Variable}

$\mathrm{Y}=$ nature of the job which is captured as a dummy variable in the model. The $\mathrm{p}$ is the probability of the odd of becoming satisfied with the job while 1-P is the otherwise.

$$
\begin{aligned}
& 1=\text { Satisfaction } \\
& 0=\text { Dissatisfaction }
\end{aligned}
$$

\section{Independent Variables}

They were 8 independent variables and they were captured as follows

$\mathbf{X}_{\mathbf{1}}=$ I feel the advent of HIV/AIDS has made my workload;

$$
\begin{aligned}
& 1=\text { less Heavy } \\
& 0=\text { Heavy }
\end{aligned}
$$

$\mathbf{X}_{\mathbf{2}}=$ how does the amount of work you are expected to do on HIV/AIDS patients influence the way you do your job.

$$
\begin{aligned}
& 1=\text { it has a good effect } \\
& 0=\text { it adversely affect the job }
\end{aligned}
$$

$\mathbf{X}_{\mathbf{3}}=$ how much pride can you take in the appearance of your work place, in the advent of HIV/AIDS?

$$
1=\mathrm{a} \text { great deal }
$$

$0=$ little

$\mathbf{X}_{4}=$ how do your physical working conditions in the advent of HIV/AIDS influence your overall attitude towards your job?

$1=$ favourable

$0=$ unfavourable

$\mathbf{X}_{\mathbf{5}}=$ considering the HIV/AIDS job, I feel the amount of money I make is:

$1=$ good

$0=$ poor

$\mathbf{X}_{\mathbf{6}}=$ does the way pay is handled around here make it worthwhile for a person to work especially hard on HIV/AIDS patients?

$$
\begin{aligned}
& 1=\text { encourages hard work } \\
& 0=\text { discourages hard work }
\end{aligned}
$$

$\mathbf{X}_{7}=$ Age of the nurses

$1=36-55$

$0=0-35$

$\mathbf{X}_{\mathbf{8}}=$ length of service

$1=16-35$

$0=0-15$ 